\title{
Plato's Educational Paradigm Shift: From Authority to Dialectic
}

\author{
Jeffrey Dirk Wilson \\ The Catholic University of America \\ Washington, D. C., United States of America
}

\begin{abstract}
Homer's Iliad and Odyssey were the educational textbooks of the Greeks which Plato sought to replace with his own work, the Republic. It was not merely that Plato wanted to replace older work with his own, rather his aim was to replace the mode of education from one of memorizing and quoting an ancient authority with the personal engagement using the dialectical method. At same time, he also sought to replace the rhetoric of seductively beautiful poetry which canonized falsehoods about the nature of the world with the sober and open-ended inquiry of questions and answers (leading to ever more questions) in prose. Thus Plato's attack on Homer was nothing less than a cultural paradigm shift from the heroic age of warfare to what Plato hoped would be an age founded upon the order of reason.
\end{abstract}

Keywords-Dialectic; Homer; Plato; Poetry; Republic; Rhetoric

\section{INTRODUCTION: EDUCATION IN PLATO'S REPUBLIC AND LAWS}

Socrates of the Republic asserts in Book 10 that between philosophy and poetry there is "an ancient quarrel." 1 That was also a way of stating Plato's own quarrel with Homer, but at the end of his life, Plato seems to have made a kind of peace between poetry and philosophy in the Laws, even a kind of peace with Homer himself. Homer appears there as the exemplary educator of the Greeks. "Education," the Stranger - the character who replaces Socrates in this last of Plato's dialogues-says, "is in our view just about the most important activity of all." $\mathrm{He}$ then summarizes his previous discussions on learning the right songs and dances as means of forming citizens who will perform both their civic and military duty. The antecedent for the personal pronouns in this passage seems to be "the human being" (â $v \theta \rho \omega \pi \circ \varsigma){ }^{3}$ This is citizenship in the broadest sense: every human living in the city, male and female alike as becomes clear in a subsequent speech. ${ }^{4}$ As authority for his view of education's

${ }^{1}$ Plato, Complete Works, trans. John M. Cooper (Indianapolis: Hackett Publishing Company, 1997), 1211, Republic 10.607b5-6; hereafter $R$. 10.607b5-6; Cooper 1211

${ }^{2}$ L. 7.803d6-7; Cooper 1472.

${ }^{3}$ L. $7.803 \mathrm{c} 4$

4 "We are not going to withdraw our recommendation that so far as possible, in education and everything else, the female sex should be on the same footing as the male." L. 7.805c6-d1; Cooper 1473. The Stranger goes on to allow for some differences, most significantly that women are not to engage in military service. L. 7.806a6-7; Cooper 1474. central place in human life, the Stranger quotes Homer, referring to him as "the poet":

He must go on his way, confident that the poet's words are true.

Some things, Telemachus, your native wit will tell you.

And Heaven will prompt the rest. The very gods, I'm sure,

Have smiled upon your birth and helped to bring you up. ${ }^{5}$

This is a quotation of the Odyssey $3.26-28,{ }^{6}$ where Athena in the guise of Mentor is speaking to Telemachus. This is a citation of Homer which is not only entirely positive, but actually refers to these lines from the Odyssey as a paradigmatic statement of education's nature. There is another passage a few pages later where the Stranger seems to bring "the ancient quarrel" to a close. ${ }^{7}$ The Stranger reflects upon the day's journey and conversation in a way that tempts the reader to wonder if this comes very close to Plato speaking of himself and the work of his lifetime. Clinias has asked for "the model work that enable him [the Guardian of the Laws] to decide what material all the children may learn." ${ }^{\prime 8}$ The Stranger answers him:

I haven't got far to look for a model. You see, when I look back over this discussion of ours, which has lasted from dawn up till this very moment - a discussion in which I think I sense the inspiration of heaven-well, it's come to look, to my eyes, just like a literary composition. Perhaps not surprisingly, I was overcome by a feeling of immense satisfaction at the sight of all 'my collected works' so to speak, because of all the addresses I have ever learned or listened to, whether in verse or in this kind of free prose style I've been using, it's these that have impressed me as being the most eminently acceptable and the most entirely appropriate for the ears of the younger generation. So I could hardly commend a better model than this to the Guardian of the Laws in charge of education. Here's what he must tell the teachers to teach the children, and if he comes across similar or related material while working through prose writings, or the verse of poets, or when listening to unwritten

\footnotetext{
${ }^{5}$ L. 7.803e5-804a3; Cooper 1472.

${ }^{6}$ Cooper 1472 n13.

7 Seth Benardete, Plato's "Laws": The Discovery of Being (Chicago: The University of Chicago Press, 2000), 215.

${ }^{8}$ L. 7.811b8-c1; Cooper 1478.
} 
compositions in simple prose that show a family resemblance to our discussion today, he must on no account let it slip through his fingers, but have them committed to writing. ${ }^{9}$

Even if one reads this passage literally and, therefore, only referring to the Laws, one sees clearly that Plato is making a joke when he says the discussion looks "just like a literary composition." Professor Benardete translates and analyzes this phrase in a way which underlines the degree to which the Stranger is settling "the ancient quarrel": "The Stranger is very pleased when he glances back at his own speeches all collected since dawn, for they suit the bill and have been spoken 'in a manner absolutely like a kind of poetry' (811c7-d5)." ${ }^{10}$ Once it is acknowledged that Plato the author jokes with his reader through the voice of the Stranger, the possibility emerges that "this discussion" refers not only to the Laws, but to the entire corpus of Plato's work, the long day of his life. Whether referring to the Laws only or to the Platonic corpus, the Stranger places the work alongside "the verse of poets." This comity of authors is not, however, absolute. When the tragedians ask for admission to the city, the Stranger proposes this response, "First of all show your songs to the authorities for comparison with ours, and if your doctrines seem the same as or better than our own, we'll let you produce your plays; but if not, friends, that we can never do." 11 This, in general, is consistent with the criteria set forth by Socrates of the Republic for readmission of Homer and other poets. ${ }^{12}$ Poets may be prohibited from entering the city, but the prohibition is particular and not categorical. With that qualification, it can be said that the works of Plato and Homer together guide the Guardian of the Laws as he educates the youth of the city.

\section{SOCRATES OF THE REPUBLIC V. HOMER}

There remains, however, the fact of the charges which Socrates of the Republic aims at Homer. What are they? Socrates summarizes much of his indictment against Homer in Books 2, 3, and 10, especially 10.595b9-608b2. First, Homer is not fit reading for young people. Reading the Iliad and the Odyssey makes them less likely to show courage in the face of battle because they will fear death ${ }^{13}$ and, further, the works encourage them "to do bad things." 14 Second, there was no Homeric way of life. Third, in relation to the principles set forth in the Divided Line, Homer presents images which are "third from the truth," 15 the lowest form of

${ }^{9}$ L. 7.811c6-e5; Cooper 1478-79.

${ }^{10}$ Benardete, "Laws," 215.

${ }^{11}$ L. 7.817d4-8; Cooper 1484

12 "If the poetry that aims at pleasure and imitation has any argument to bring forward that proves it ought to have a place in a well-governed city, we at least would be glad to admit it." $R$. 10.607c3-6; Cooper 1211 .

13 "Then we must supervise such stories and those who tell them, and ask them not to disparage the life in Hades in this unconditional way, but rather to praise it, since what they now say is neither true nor beneficial to future warriors." R. 3.386b8-c1; Cooper 1022.

14 "For that reason, we must put a stop to such stories, lest they produce in the young a strong inclination to do bad things." $R$. 3.391e12-392a1; Cooper 1029.

${ }^{15} R$. 10.602c1-2; Cooper 1206. It needs to be noted that in the Divided Line, there are four levels of reality: Forms, mathematical objects, things, and images $(R$. 6.509d6-511c2). In $R$. 10.597b5-7, there are only three levels of reality. Fourth, while images are of the lowest form of reality, they are still something of reality, but Homer compounds this failing by presenting false images, thus even accuracy is lacking in the representations of reality at the lowest form. This charge applies especially to Homeric depiction of the gods. ${ }^{16}$ For Socrates of the Republic, philosophy is metaphysics, the science of being. Homer's representation of gods in flux is to reduce being to mere becoming. ${ }^{17}$ Fifth, the most explicitly damning charge against Homer, however, is that he makes those false images so beautiful ${ }^{18}$ that even the super-rational Socrates finds them hard to resist. ${ }^{19}$ Professor Gilbert Murray comments on this point about Plato, "Poetry was to him a seducing fire." ${ }^{20}$ Sixth and finally, there is also a subtler and more pervasive reason for attacks on Homer, one that goes beyond the Republic. This reason is harder to find in the Platonic text because of the reason itself. It also goes far in explaining why Plato never writes in his own voice and why Socrates will not allow himself to be pinned down to a specific teaching. The reason is that Plato rejected the notion of an authority which someone could appropriate by proof-texting a passage from the authority's work. In a sense, this is not a charge against Homer himself, rather a charge against the way Homer was received in fifth and fourth century B.C. Athens. The problem is one Xenophanes had already determined, "Since from the beginning all have learned according to Homer." ${ }^{21}$ The issue was Homeric authority and how that authority was invoked. Plato did not want "according to Homer" to be replaced by "according to Plato" or "according to Socrates." This principle guided Plato in his writing, but precisely because of the principle it had to be expressed implicitly. It is ironically humorous when one considers the extent to which Plato failed in this part of his endeavor. Despite the fact that Plato never in the dialogues speaks in his own voice, philosophers opine without end, "According to Plato ...."

reality: the Form of the bed, the bed built by a carpenter, and the bed painted by a painter. Missing is the level of mathematical objects. The fourth and lowest in $R .6 .509 \mathrm{~d} 6-511 \mathrm{c} 2$ is third and lowest in $R .10 .597 \mathrm{~b} 5-7$.

16 "As we said earlier, these things are both impious and untrue, for we demonstrated that it is impossible for the gods to produce bad things." $R$. 3.391d7-e2; Cooper 1029.

17 "Is it impossible, then, for gods to want to alter themselves? Since they are the most beautiful and best possible, it seems that each always and unconditionally retains his own shape." $R$. 2.381c7-9; Cooper 1020.

18 "Nonetheless, he'll go on imitating, even though he doesn't know the good or bad qualities of anything, but what he'll imitate, it seems is what appears fine or beautiful to the majority." $R$. 10.602b1-4; Cooper 1206.

19 "However, we haven't yet brought the most serious charge against imitation, namely, that with a few rare exceptions it is able to corrupt even decent people, for that's surely an altogether terrible thing. . . . Listen, then, and consider whether it can or not. Even when the best of us hear Homer or some other tragedian imitating one of the heroes sorrowing and making a long lamenting speech or singing and beating his breast, you know that we enjoy it, give ourselves up to following it, sympathize with the hero, take his sufferings seriously, and praise as a good poet the one who affects us most in this way." $R .10 .605 \mathrm{c} 6-8, \mathrm{c} 10-\mathrm{d} 5$; Cooper 1210.

${ }^{20}$ Gilbert Murray, The Rise of Greek Epic (New York, Oxford University Press, 1960), 91.

${ }^{21}$ Die Fragmente der Vorsokratiker. 3 vols. Edited by Hermann Diels, and Walther Kranz.

6th ed. Berlin: Weidmannsche Verlagsbuchhandlung, 1951 (reprint 1960). Xenophanes, B10 D.-K.; J. H. Lesher, Xenophanes of Colophon Fragments. a Text and Translation with Commentary (Toronto: University of Toronto Press, 1992), 21. 


\section{A QUESTION OF AUTHORITY}

Plato rejected the kind of authority which was attributed to Homer. $^{22}$ Towards that end, Plato has Socrates cut Homer down to size. An irony in the authoritative position of Homer is that by accepting it, his interpreter participates in Homeric authority. This seems to be part of what Plato found wrong with allegorical or metaphorical interpretation: it leaves the interpreter in possession of Homer and his authority. Plato seeks to set forth a different kind of authority, one that is, at once, both more exclusive and more available than an authoritative author, namely the authority of rational argument. It is more exclusive because it cannot be taught to every child of the city in the way recitation of Homeric texts can be taught. At the same time, it is more available because it actually insists on at least one partner in conversation. This is a fundamental shift from rhetoric, which may be defined as persuasive explanation of and for a known truth-claim, to dialectic, which can be defined as argument toward an as yet unknown truth-claim. Socrates of the Phaedrus points to this problem with Homer. He is an authority recited to convince rather than to engage in dialogue. Socrates of the Phaedrus condemns certain writings, "Those that are recited in public without questioning and explanation, in the manner of the rhapsodes, are given only in order to produce conviction."23 Rather than trying to convince people to hold this view or that notion, Plato's aim is to persuade people to think. Plato's challenge was how to be an author without becoming an authority. Professor Kahn comments upon Plato's motive:

His principal aim, above all in the earlier works, is not to assert true propositions but to alter the minds and hearts of his readers. Plato's conception of philosophical education is not to replace false doctrines with true ones but to change radically the moral and intellectual orientation of the learner, who, like the prisoners in the cave, must be converted-turned around-in order to see the light. ${ }^{24}$

To continue using the imagery of the Cave, it is not, then, enough, to make better shadow puppets. The problem is not primarily in what is seen, rather in the mode of seeing. No longer should people see with their eyes, rather with their rational souls. Thus dialectic becomes the new authority replacing the old "According to . . ." and not merely "According to Homer," rather also "According to anybody at all."

\footnotetext{
${ }^{22}$ Professor Nightingale observes that the "ancient quarrel" has to do with the David-like new discipline of philosophy taking on the Goliath of poetry, "By announcing a quarrel between philosophy and poetry, in short, Plato emphasizes that the discussion of poetry directly reflects upon the nature of philosophy. At the same time, he invests philosophy with an extraordinary status - a status that it certainly did not have in this period. For philosophy now emerges as the powerful adversary of the giant that is poetry. By picking a quarrel with poetry, in sum, Plato tries to have it both ways: although philosophers are a new and 'tiny' group, they are engaged in an epic battle with the poets." Andrea Wilson Nightingale, Genres in Dialogue: Plato and the Construct of Philosophy (Cambridge: Cambridge University Press, 1995), 67.

${ }^{23}$ Phdr. 277e8-278a1; Cooper 554.

${ }^{24}$ Charles H. Kahn, Plato and the Socratic Dialogue. The Philosophical Use of a Literary Form (Cambridge: Cambridge University Press, 1998), xiv.
}

Professor David Sedley, after discounting the notion that Plato does not appear in his dialogues as a means of distancing himself from what is said there, offers insight consistent with but not the same as that of Professor Kahn:

Plato's real reason for persisting with the dialogue form is, I think, a very different one, his growing belief-more than once made explicit in his later work - that conversation, in the form of question and answer, is the structure of thought itself. When we think, what we are doing is precisely to ask and answer questions internally, and our judgements are the outcome of that same process. Hence it seems that what Plato dramatizes as external conversations can be internalized by us, the readers, as setting the model for our own processes of philosophical reasoning. . . . Plato's very word for philosophical method 'dialectic,' means quite literally the science

of conducting a conversation in this question-and-answer form, and it is vital to appreciate that the inter-personal discussion portrayed in the dialogues is not the only mode in which such discussion can occur: internal discussion is another, and perhaps even more fundamental, mode. ${ }^{25}$

It may be that Plato was merely mimicking what he observed about human thought (i.e., an imaged description) as Professor Sedley suggests, but it may also be, the view held here, that Plato was contributing, perhaps without knowing it, to changing the way humans think (i.e., an imaged prescription). Plato may have assumed that this is the way people really always thought, but that they just did not know it, and by writing his dialogues he made true what he thought had already been true. To speak anachronistically, this inversion could be called "Plato's Copernican revolution," as an analogue to Kant's Copernican revolution in which Kant proposed that in fact concepts had always existed in the human mind prior to experience, but that until he noticed the fact no one else had. ${ }^{26}$ Plato's commitment not to replace "according to Homer" with "according to Socrates" or "Plato," determined how he must write.

\section{CONCLUSION}

Inter-cultural communication usually refers to how different contemporary cultures address each other, in other words synchronic communication. The point which emerges from this consideration is that there is also the necessity of studying diachronic inter-cultural communication. History entails cultural transformation. Though the people speak the same language as their ancestors, in many respects they live in a different world. That was the circumstance which Plato

\footnotetext{
${ }^{25}$ David Sedley, Plato 's Cratylus (Cambridge: Cambridge University Press, 2003), 1-2.

${ }^{26}$ For example, Kant writes, "Hume's problem rescues for the pure concepts of the understanding their a priori origin and for the universal laws of nature their validity as laws of the understanding, yet in such a way as to limit their use to experience, because their possibility depends solely on the reference of the understanding to experience, but with a completely reversed mode of connection which never occurred to Hume: they are not derived from experience, but experience is derived from them." Immanuel Kant, Prolegomena to Any Future Metaphysics, $2^{\text {nd }}$ ed., trans. James W. Ellington (Indianapolis: Hackett Publishing Company, 2002), 313.
} 
recognized in fourth B.C. Athens and which he sought to address with a new educational paradigm.

Plato did not merely want to replace older work with his own, rather his aim was to replace the mode of education from one of memorizing and quoting an ancient authority with personal engagement using the dialectical method. At same time, he also sought to replace the rhetoric of seductively beautiful poetry which canonized falsehoods about the nature of the world, with the sober and open-ended inquiry of questions and answers (leading to ever more questions) in prose. Thus Plato's attack on Homer was nothing less than a cultural paradigm shift from the heroic age of warfare to what Plato hoped would be an new age founded upon the order of reason.

\section{REFERENCES}

[1] Benardete, Seth. Plato's "Laws": The Discovery of Being. Chicago: The University of Chicago Press, 2000.

[2] Die Fragmente der Vorsokratiker. 3 vols. Edited by Hermann Diels, and Walther Kranz. 6th ed. Berlin: Weidmannsche Verlagsbuchhandlung, 1951 (reprint 1960).

[3] Kahn, Chalres H. Plato and the Socratic Dialogue. The Philosophical Use of a Literary Form. Cambridge: Cambridge University Press, 1998.

[4] Kant, Immanuel. Prolegomena to Any Future Metaphysics. Second Edition. Translated by James W. Ellington. Indianapolis: Hackett Publishing Company, 2002.

[5] Lesher, J. H. Xenophanes of Colophon. Fragments: a Text and Translation with Commentary. Toronto: University of Toronto Press, 1992.

[6] Murray, Gilbert. The Rise of Greek Epic. New York: Oxford University Press, 1960.

[7] Plato. Complete Works. Edited with Introduction and Notes by John M. Cooper. Indianapolis: Hackett Publishing Company, 1997.

[8] Sedley, David. Plato's “Cratylus”. Cambridge: Cambridge University Press, 2003. 